\title{
Effects of Yuhyangjeongtong-san on Fracture Healing in Rats
}

\author{
Ki-Tae Kim ${ }^{1}$, Na-Young $\mathrm{Jo}^{2^{*}}$ \\ ${ }^{1}$ Dept. of Internal Medicine, Je-Cheon Hospital of Traditional Korean Medicine, Semyung University \\ ${ }^{2}$ Dept. of Acupuncture \& Moxibustion Medicine, Je-Cheon Hospital of Traditional Korean Medicine, \\ Semyung University
}

\begin{abstract}
Objectives: The purpose of this study is to determine the effect of Yuhyangjeongtong-san on the recovery of tibial fractures in rats.

Methods: In this study, osteocalcin and Calcitonin, CTX-2, TGF- $\beta$ and BMP-2, which are used as indicators of bone formation, were analyzed after hematologic fractures using experimental rats. In addition, the fracture union process was confirmed using X-rays.

Results: Osteocalcin, Calcitonin and BMP-2 showed a significant increase compared with the control at 4 weeks. CTX-2 and TGF- $\beta$ showed a significant increase compared with the control at 3 weeks. On X-ray, YJS treated group, as the experiment progressed, the boundary line became blurred, the bone outline was clearly visible, and the fracture recover was progressing.

Conclusion: The findings suggest that YJS can play a significant role in the repair of fractures. Therefore YJS is likely to be used to treat fractures.
\end{abstract}

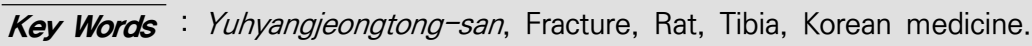

\section{Introduction}

A fracture is a condition in which the continuity of a bone is completely or incompletely lost or a linear deformation occurs. Fractures are mostly accompanied by damage to the skin, subcutaneous tissue, fascia, blood vessels, and nerves ${ }^{1)}$. Elderly people are more likely to experience fractures with a small impact. In addition, the risk of fracture increases as the proportion of sporting activities performed in their spare time increases ${ }^{2)}$.
Fractures differ according to their location and extent, but most require conservative or surgical treatment, such as a splint fixation or gypsum fixation $^{3)}$. This treatment process leads to limited activity and a long treatment duration, which causes a great loss not only for each individual but also for society. In general, various methods, such as weight bearing, fixation, and drug administration, are used for promoting the Western healing of fractures ${ }^{4}$. Therefore, new therapies are needed to complement or replace existing ones.

- Received : 19 November 2019

- Revised : 27 November 2019

- Accepted : 29 November 2019

- Correspondence to : Na-Young Jo

Dept. of Acupuncture \& Moxibustion Medicine, Je-Cheon Hospital of Traditional Korean Medicine, Semyung University Semyungro 66, sinwoul-dong, jecheon city, chungbuk, 27136, Republic of Korea

Tel : +82-43-649-1825, Fax : +82-43-645-1382, E-mail : cswcny2@hanmail.net 
Fractures heal through inflammatory, restorative, and remodeling phases. Chinese herbal medicine has the advantage of selecting an effective drug through the dialectic according to the healing stage of these fractures ${ }^{1}$. Therefore, personalized treatment according to the present condition of the patient is possible. In addition, it is expected that the treatment period may be shortened by administering an herbal medicine that promotes bone union in patients who have undergone conventional orthopedic treatment. In particular, in elderly patients, it is possible to combine drugs in the consideration of systemic conditions. To take advantage of such herbal treatments, an experimental study on herbal medicines that acts at each stage of healing must be performed.

In the previous study, there was experiment for the results of Yukmijihwang-tang and Cervi Pantotrichum Cornu ${ }^{5}$ administration for fracture treatment. There were three trials in which Neutral Eohyeol(Yuxue) Herbal Acupuncture and Dangkisoo-san $^{6}$ was administered to treat fractures. For monodrugs, Pyritum ${ }^{7}$ was used. As a combination drug, Jeopgolsan ${ }^{8)}$ and Bokwonhwalhyul-tang ${ }^{9)}$ has been reported to have a significant effect. There is a need for systematic research on more diverse Korean herbal prescriptions.

Yuhyangjeongtong-san(YJS) is a medicine used for injuries. It is said that this is effective for trauma, such as bruises ${ }^{10)}$. Previous studies have shown that YJS is effective for arthritis ${ }^{11)}$. Clinically, it has been reported to be effective in reducing pain from injuries caused by traffic accidents ${ }^{12)}$. Therefore, YJS is expected to be effective for fracture union. However, there has been no study on YJS and fracture recovery.

The authors thought that the initial treatment of fractures was anti-inflammatory. In this study, osteocalcin and Calcitonin, CTX-2, TGF- $\beta$ and BMP-2, which are used as indicators of bone formation, were analyzed after hematologic fractures using experimental rats. In addition, the fracture union process was confirmed using X-rays. Based on the experimental results, we obtained knowledge about the effects of YJS fracture repairs.

\section{Materials and Methods}

\section{Materials}

1) Cells

RAW 264.7 cells were purchased from Korea Cell Line Bank (Seoul, Korea).

2) Medicinal herbs

The composition of the medicine was referred to Donguibogam ${ }^{10}$. The medicinal herbs that the frankincense (hereinafter referred to as YJS) used in this experiment were purchased through OmniHub (Daegu, Korea) (Table 1).

Table 1. Prescription of Yuhyangjeongtong-san per Pack in Donguibogam

\begin{tabular}{lc}
\hline \multicolumn{1}{c}{ pharmacological name } & Dose $(\mathrm{g})$ \\
\hline Angelicae Dahuricae Radix & $4 \mathrm{~g}$ \\
Angelicae Gigantis Radix & $4 \mathrm{~g}$ \\
Rhmanniae Radix & $4 \mathrm{~g}$ \\
Moutan Cortex & $4 \mathrm{~g}$ \\
Paeoniae Radix Rubra & $4 \mathrm{~g}$ \\
Cnidii Rhizoma & $4 \mathrm{~g}$ \\
Olibanum & $4 \mathrm{~g}$ \\
Myrrha & $4 \mathrm{~g}$ \\
Atractylodis Macrocephalae Rhizoma & $4 \mathrm{~g}$ \\
Glycyrrhizae Radix & $4 \mathrm{~g}$ \\
Total & $40 \mathrm{~g}$ \\
\hline
\end{tabular}

3) Animals

5-week-old male SD(Sprague-Dawley) Rat (120 $130 \mathrm{~g}$ ) was supplied from Samtaco (Gyeonggi-do, 
Korea). Humidity was maintained at $55 \pm 15 \%$ at $2{ }^{\circ} \mathrm{C}$., adapted for 2 weeks in a 12-12 hour (light-dark cycle) environment. Rats were divided into three groups of 12 animals each. Normal group was fed saline without causing fracture. The control group induced fractures and fed saline. The YJS group fed $2 \mathrm{ml}$ of YJS concentrate at $200 \mu \mathrm{g} / \mathrm{ml}$ after the fracture.

\section{Methods}

\section{1) Specimen}

YJS 5packs (200 g) was added 4,000 $\mathrm{ml}$ of DW and extracted for 4 hours filtrate was obtained and concentrated under reduced pressure using a rotary vacuum evaporator. As a concentrated solution, $19.7 \mathrm{~g}$ of lyophilized powder was obtained using a freeze dryer (yield 9.85\%), and the obtained powder was used after diluting to a required while being stored in a cryogenic freezer $\left(-80{ }^{\circ} \mathrm{C}\right)$.

\section{2) Culture of RAW 264.7}

The frozen 264.7 cells were transferred to a $50 \mathrm{ml}$ tube, and $9 \mathrm{ml}$ of PBS was added. The cells were suspended centrifuged at 1,200 rpm for 5 minutes, and the supernatant was removed. $1 \mathrm{ml}$ of $1 \%$ penicillin and $10 \%$ fetal bovine serum (FBS) were added to the tube containing cells, and $1 \mathrm{ml}$ of DMEM was suspended. A total of 9 $\mathrm{ml}$ of medium was placed on a $100-\mathrm{mm}$ dish, and the cells were suspended and incubated with a cell incubator $\left(37{ }^{\circ} \mathrm{C}, 5 \% \mathrm{CO}_{2}\right)$. The number of passages was 10 times or less. Twenty-four hours were adapted before processing the samples.

\section{3) Cytotoxicity}

RAW 264.7 cells were dispensed at $1 \times 10^{5}$ cells/well in96-well plates and incubated for 24hours. Before the start of the experiment was replaced with a new culture, YJS was treated at concentrations of $10,50,100,200$, and $400 \mu \mathrm{g} / \mathrm{ml}$ and incubated for 24 hours. After incubation, 10 $\mu \mathrm{l}$ of water-soluble tetrazolium salt solution was added, followed by reaction for 30 minutes using a cell incubator $\left(37^{\circ} \mathrm{C}, 5 \% \mathrm{CO}_{2}\right)$. The change in absorbance at $450 \mathrm{~nm}$ was measured to express the survival rate of the cells as a percentage with respect to the control group.

\section{4) Tibial fracture induction}

The animals were anesthetized by intraperitoneal injection $1 \mathrm{mg} / \mathrm{kg}$ zoletil. After anesthesia, the left hind legs of the experimental animals were placed on a flat plate and a blunt blade composed of was placed in the middle of the tibia. A tube with a diameter of $3.5 \mathrm{~cm}$ and a length of $70 \mathrm{~cm}$ was erected on a blunt blade, and then a metal weight of $18 \mathrm{~g}$ and $3 \mathrm{~cm}$ in diameter was dropped. After confirming the fracture, the fracture site was fixed with fixed tape for an orthopedic sprint (Kumjeong Chemical, Korea).

5) Group assignment and sample processing

The experiment was divided into three groups, and 12 animals were assigned to each group. Once daily, at $2 \mathrm{pm}, 2 \mathrm{ml}$ was administered orally. We followed allowable dose per $100 \mathrm{~g}$ per SD rat according to the KFDA Animal Testing Guidelines. A free diet was provided during the experiment. Oral administration was performed for a total of 4 weeks at time point 0 when a tibia fracture was induced.

\section{6) Serum separation}

In the experiments, $0,1,2,3$, and 4 weeks after anesthesia with ethyl ether, blood was 
collected by cardiac puncture and centrifuged at $3,000 \mathrm{rpm}$ for 15 minutes to determine the factors related to fracture healing.

7) In vivo

(1) Osteocalcin measurement

Osteocalcin was measured using Osteocalcin ELISA kit (R \& D, U.S.A). A total of $100 \mu \mathrm{l}$ of biotinylated osteocalcin was dispensed into each well and plate mixed for 30 minutes. After washing the coated plate with the washing buffer solution, primary antibody, primary incubation buffer, standard, control, and serum added and plate mixed for 1 hour. After washing with the washing buffer solution again, $100 \mu \mathrm{l}$ of secondary antibody was added to each well for 15 minutes, plate mixing was performed, $100 \mu \mathrm{l}$ of stop solution was added, and the absorbance was measured at $450 \mathrm{~nm}$ using an ELISA reader.

(2) Calcitonin and CTX II measurement

Calcitonin and CTXII were measured using a calcitonin and CTXII ELISA kit (MyBioSource, U.S.A.). A total of $50 \mu \mathrm{l}$ of the standard, control, and serum was dispensed into each well, $100 \mu \mathrm{l}$ of horse radish peroxidase-conjugate was added and mixed, and the resultant was placed in an incubator at $37{ }^{\circ} \mathrm{C}$ for 1 hour. After the reaction was washed with a washing buffer solution, 100 ulof the chromogen solution was reacted for 15 minutes in an incubator at $37{ }^{\circ} \mathrm{C}$ again. Finally, $50 \mu 1$ of stop solution was added and the absorbance was measured at $450 \mathrm{~nm}$ using an ELISA reader.

(3) TGF- $\beta$ and BMP-2 measurement

TGF- $\beta$ and BMP-2 were measured using the TGF- $\beta$ and BMP-2 ELISA kits (R \& D, U.S.A).
First, $1 \mathrm{~N}$ HCI solution was added to $40 \mu \mathrm{l}$ of serum for 10 minutes in a $37{ }^{\circ} \mathrm{C}$ incubator for TGF- $\beta$ measurement, and then $10 \mu \mathrm{l}$ of $1.2 \mathrm{~N}$ $\mathrm{NaOH} / 0.5 \mathrm{M}$ HEPES was mixed to prepare a sample. Afterward, $50 \mu \mathrm{l}$ of assay diluent was added to each well for $\beta$ measurement , $100 \mu \mathrm{l}$ of BMP-2 was measured, and $50 \mu \mathrm{l}$ of the standard, control, and serum was added for 2 hours. The reaction was carried out in an incubator at $37^{\circ} \mathrm{C}$, and the BMP-2 measuring plate was mixed. After washing with a washing buffer solution, $100 \mu \mathrm{l}$ of TGF- $\beta$ conjugate and $200 \mu$ of BMP- 2 conjugate were added and reacted for another 2 hours. After the reaction, the resultant was washed with washing buffer solution again, $100 \mu \mathrm{l}$ and $200 \mu \mathrm{l}$ of substrate solution were reacted for 30 minutes, and $100 \mu \mathrm{l}$ and $50 \mu \mathrm{l}$ of stop solution were measured absorbance was measured at $450 \mathrm{~nm}$ using an ELISA reader.

8) Radiography

X-rays were taken at weeks 0,2 , and 4 using an Inalizer (Medikors, Korea).

\section{Statistical processing}

The results were expressed as mean \pm standard deviation (Mean \pm S.D.) using the SPSS 18.0 statistical program, and the significance was verified at the $*: \mathrm{p}<0.05$, and $* *: \mathrm{p}<0.01$, using ANOVA and the post-hoc Duncan test.

\section{Result}

\section{Cytotoxicity}

YJS was administered to the RAW 264.7 cells at different concentrations, and the cell viability was measured. As a result, cell viability rates of $100.00 \pm 0.73 \%, 99.23 \pm 1.72 \%, 98.51 \pm 1.27 \%$, 
$97.47 \pm 2.53 \%, 93.29 \pm 2.56 \%$, and $88.17 \pm$ $2.65 \%$ were observed at the concentrations of the control at 10, 50, 100, 200, and $400 \mathrm{\mu g} / \mathrm{ml}$, respectively. At concentrations above $400 \mu \mathrm{g} / \mathrm{ml}$, there was a significant decrease in cells (Fig. 1).

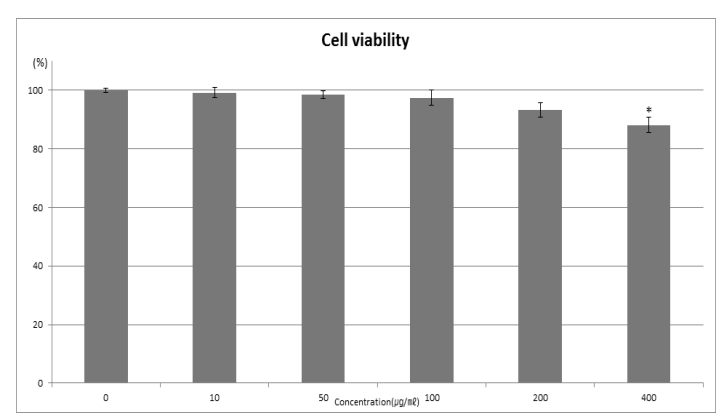

Fig. 1. Cell viability of YJS extract in RAW 264.7 cells. The results were represent the mean \pm S.D. (Significance of result, : $p\langle 0.05$ compared to control)

\section{Osteocalcin production}

Effects on osteocalcin production were observed. As a result, the osteocalcin production rates of $0.70 \pm 0.04 \mathrm{pg} / \mathrm{ml}, 0.71 \pm 0.02 \mathrm{pg} / \mathrm{ml}, 0.72 \pm 0.01 \mathrm{pg} / \mathrm{ml}$, $0.71 \pm 0.06 \mathrm{pg} / \mathrm{ml}$, and $0.73 \pm 0.02 \mathrm{pg} / \mathrm{ml}$ were observed at $0,1,2,3$ and 4 weeks respectively on normal. production rates of $0.69 \pm 0.03 \mathrm{pg} / \mathrm{ml}$, $10.36 \pm 0.17 \mathrm{pg} / \mathrm{ml}, 9.78 \pm 0.46 \mathrm{pg} / \mathrm{ml}, 9.06 \pm 0.37$ $\mathrm{pg} / \mathrm{ml}$, and $8.32 \pm 0.28 \mathrm{pg} / \mathrm{ml}$ were observed at 0 , $1,2,3$ and 4 weeks respectively on control. production rates of $0.73 \pm 0.03 \mathrm{pg} / \mathrm{ml}, 10.21 \pm$ $0.26 \mathrm{pg} / \mathrm{ml}, 11.54 \pm 0.53 \mathrm{pg} / \mathrm{ml}, 10.53 \pm 0.47 \mathrm{pg} / \mathrm{ml}$, and $9.82 \pm 0.34 \mathrm{pg} / \mathrm{ml}$ were observed at $0,1,2,3$ and 4 weeks respectively on YJS at concentration $200 \mu \mathrm{g} / \mathrm{ml}$. There was a significant increase in cells at concentratio at week 4 (Fig. 2).

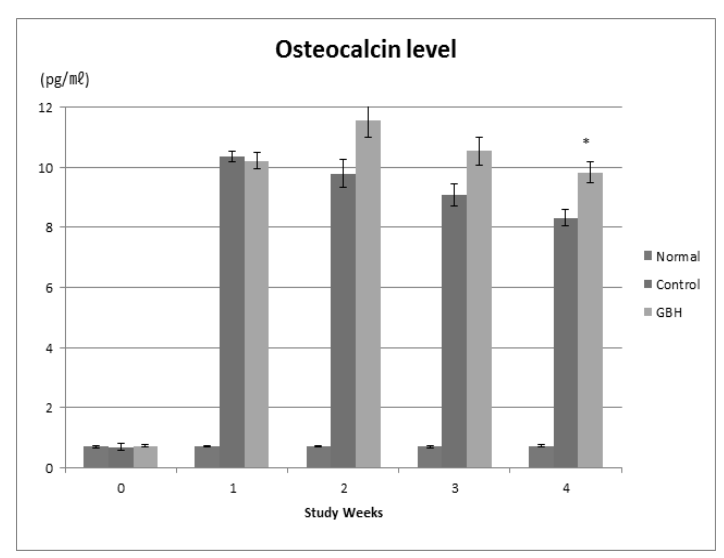

Fig. 2. Effect of YJS on the level of Osteocalcin in serum of tibia fractured rat. The result were represent the mean \pm S.D. (Significance of result,: :p<0.05 compared to control)

\section{Calcitonin Production}

Effects on calcitonin production were observed. As a result, the calcitonin production rates of 2.31 $\pm 0.15 \mathrm{pg} / \mathrm{ml}, 2.36 \pm 0.24 \mathrm{pg} / \mathrm{ml}, 2.43 \pm 0.17 \mathrm{pg} /$ $\mathrm{ml}, 2.24 \pm 0.14 \mathrm{pg} / \mathrm{ml}$, and $2.25 \pm 0.13 \mathrm{pg} / \mathrm{ml}$ were observed at $0,1,2,3$ and 4 weeks respectively on normal. production rates of $2.45 \pm 0.17 \mathrm{pg} / \mathrm{ml}$, $2.43 \pm 0.29 \mathrm{pg} / \mathrm{ml}, 2.58 \pm 0.23 \mathrm{pg} / \mathrm{ml}, 2.93 \pm 0.18$ $\mathrm{pg} / \mathrm{ml}$, and $2.61 \pm 0.21 \mathrm{pg} / \mathrm{ml}$ were observed at 0 , $1,2,3$ and 4 weeks respectively on control. production rates of $2.42 \pm 0.15 \mathrm{pg} / \mathrm{ml}, 2.41 \pm 0.27$ $\mathrm{pg} / \mathrm{ml}, 2.32 \pm 0.18 \mathrm{pg} / \mathrm{ml}, 3.72 \pm 0.15 \mathrm{pg} / \mathrm{ml}$, and $4.61 \pm 0.28 \mathrm{pg} / \mathrm{ml}$ were observed at $0,1,2,3$ and 4 weeks respectively on YJS at concentration 200 $\mu \mathrm{g} / \mathrm{ml}$. There was a significant increase in cells at concentratio at week 4 (Fig. 3).

\section{CTX-2 production}

Effects on CTX-2 production were observed. As a result, the CTX-2 production rates of 917.31 $\pm 70.02 \mathrm{pg} / \mathrm{ml}, 954.44 \pm 40.58 \mathrm{pg} / \mathrm{ml}, 932.37 \pm$ $20.05 \mathrm{pg} / \mathrm{ml}, 923.32 \pm 30.53 \mathrm{pg} / \mathrm{ml}$, and $924.37 \pm$ 


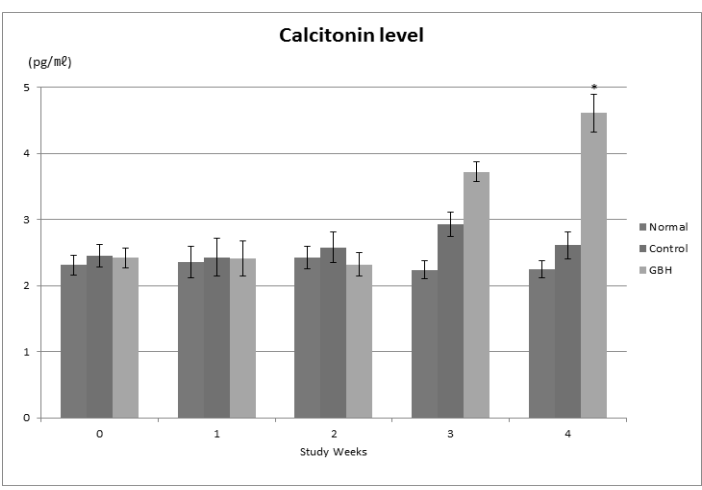

Fig. 3. Effect of YJS on the level of Calcitonin in serum of tibia fractured rat. The result were represent the mean \pm S.D. (Significance of result, $*: p<0.05$ compared to control).

$30.39 \mathrm{pg} / \mathrm{ml}$ were observed at $0,1,2,3$ and 4 weeks respectively on normal. production rates of $914.37 \pm 60.11 \mathrm{pg} / \mathrm{ml}, 1315.85 \pm 20.15 \mathrm{pg} / \mathrm{ml}$, $1227.65 \pm 30.56 \mathrm{pg} / \mathrm{ml}, 1344.04 \pm 50.08 \mathrm{pg} / \mathrm{ml}$, and $1312.91 \pm 40.91 \mathrm{pg} / \mathrm{ml}$ were observed at 0,1 , 2, 3 and 4 weeks respectively on control. production rates of $946.43 \pm 70.03 \mathrm{pg} / \mathrm{ml}, 1232.41$ $\pm 60.54 \mathrm{pg} / \mathrm{ml}, 1133.28 \pm 10.82 \mathrm{pg} / \mathrm{ml}, 928.40 \pm$ $80.14 \mathrm{pg} / \mathrm{ml}$, and $901.37 \pm 30.75 \mathrm{pg} / \mathrm{ml}$ were observed at $0,1,2,3$ and 4 weeks respectively on YJS at concentration $200 \mu \mathrm{g} / \mathrm{ml}$. There was a significant decrease in cells at concentratio at week 3 (Fig. 4).

\section{TGF- $\beta$ Production}

Effects on TGF- $\beta$ production were observed. As a result, the TGF- $\beta$ production rates of 500.61 $\pm 1.31 \mathrm{pg} / \mathrm{ml}, 499.43 \pm 1.76 \mathrm{pg} / \mathrm{ml}, 501.62 \pm 1.42$ $\mathrm{pg} / \mathrm{ml}, 500.84 \pm 1.25 \mathrm{pg} / \mathrm{ml}$, and $499.75 \pm 1.89 \mathrm{pg} /$ $\mathrm{ml}$ were observed at $0,1,2,3$ and 4 weeks respectively on normal. production rates of $500.23 \pm 1.50 \mathrm{pg} / \mathrm{ml}, 1113.12 \pm 63.56 \mathrm{pg} / \mathrm{ml}$, $1038.90 \pm 22.29 \mathrm{pg} / \mathrm{ml}, 977.48 \pm 53.23 \mathrm{pg} / \mathrm{ml}$, and $845.68 \pm 24.51 \mathrm{pg} / \mathrm{ml}$ were observed at $0,1,2,3$

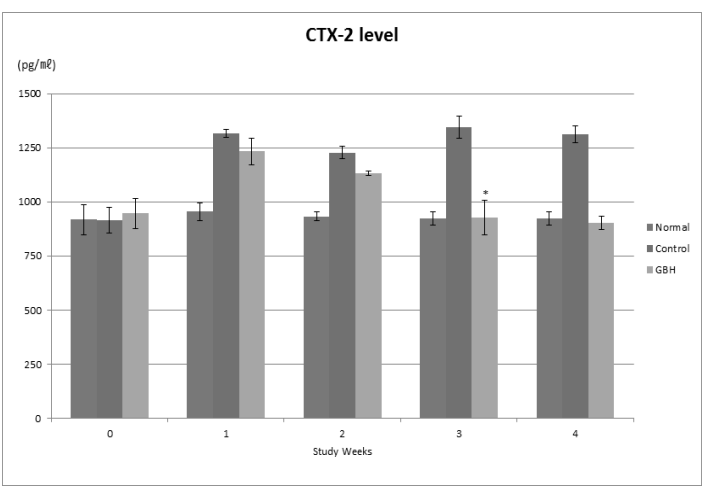

Fig. 4. Effect of YJS on the level of CTX-2 in serum of tibia fractured rat. The result were represent the mean \pm S.D. (Significance of result, *::p $\langle 0.05$ compared to control)

and 4 weeks respectively on control. production rates of $501.18 \pm 34.54 \mathrm{pg} / \mathrm{ml}, 1224.37 \pm 17.42$ $\mathrm{pg} / \mathrm{ml}, 1217.58 \pm 29.84 \mathrm{pg} / \mathrm{ml}, 1274.29 \pm 41.13$ $\mathrm{pg} / \mathrm{ml}$, and $923.96 \pm 46.51 \mathrm{pg} / \mathrm{ml}$ were observed at $0,1,2,3$ and 4 weeks respectively on YJS at concentration $200 \mu \mathrm{g} / \mathrm{ml}$. There was a significant inecrease in cells at concentratio at week 3(Fig. $5)$.

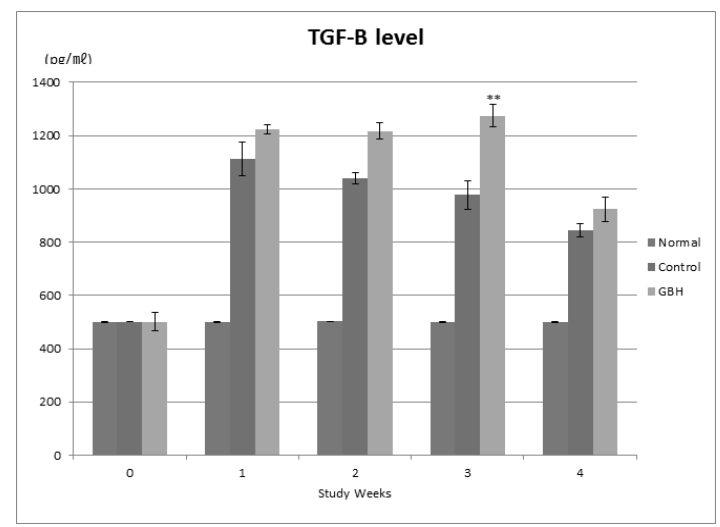

Fig. 5. Effect of YJS on the level of TGF- $\beta$ in serum of tibia fractured rat. The result were represent the mean \pm S.D. (Significance of result, **:p<0.01 compared to control) 


\section{BMP-2 production amount}

Effects on BMP-2 production were observed. As a result, the BMP-2 production rates of $148.82 \pm 1.93 \mathrm{pg} / \mathrm{ml}, 150.31 \pm 2.45 \mathrm{pg} / \mathrm{ml}, 149.29$ $\pm 2.38 \mathrm{pg} / \mathrm{ml}, 148.63 \pm 1.76 \mathrm{pg} / \mathrm{ml}$, and $150.75 \pm$ $3.21 \mathrm{pg} / \mathrm{ml}$ were observed at $0,1,2,3$ and 4 weeks respectively on normal. production rates of $150.67 \pm 1.14 \mathrm{pg} / \mathrm{ml}, 181.14 \pm 3.29 \mathrm{pg} / \mathrm{ml}, 197.37$ $\pm 4.04 \mathrm{pg} / \mathrm{ml}, 184.66 \pm 4.04 \mathrm{pg} / \mathrm{ml}$, and $175.23 \pm$ $5.73 \mathrm{pg} / \mathrm{ml}$ were observed at $0,1,2,3$ and 4 weeks respectively on control. production rates of $148.63 \pm 8.09 \mathrm{pg} / \mathrm{ml}, \quad 180.04 \pm 10.34 \mathrm{pg} / \mathrm{ml}$, $171.07 \pm 8.29 \mathrm{pg} / \mathrm{ml}, 157.28 \pm 9.94 \mathrm{pg} / \mathrm{ml}$, and $143.96 \pm 8.41 \mathrm{pg} / \mathrm{ml}$ were observed at $0,1,2,3$ and 4 weeks respectively on YJS at concentration $200 \mu \mathrm{g} / \mathrm{ml}$. There was a significant decrease in cells at concentratio at week 3 and 4 (Fig. 6).

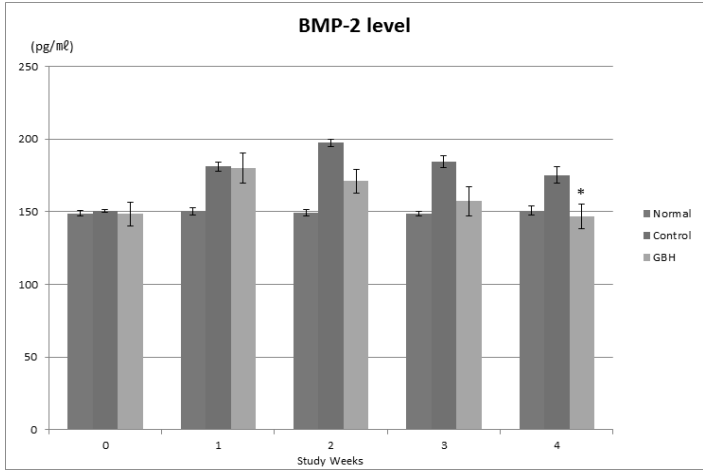

Fig. 6. Effect of YJS on the level of BMP-2 in serum of tibia fractured rat. The result were represent the mean \pm S.D. (Significance of result, *:p<0.05 compared to control)

\section{Radiation}

To determine the effects of YJS on tibial fracture union, $\mathrm{X}$-rays were taken every two weeks from 0 to 4 weeks after a tibial fracture. Control group has the borderline remained and fusion was in progress. On the other hand, in the YJS treated group, as the experiment progressed, the boundary line became blurred, the bone outline was clearly visible, and the fracture recover was progressing. (Fig. 7).

\section{Discussion}

A fracture is a condition in which bone continuity is lost completely or incompletely. In Korean medicine Uijonggeumgam and Sanggwaboyo, the study of fractures has become more systematic. According to the literature, Cheongeumyobang proposes methods of reduction and fixation. It also describes the use of drug therapy in Taepyeonghyeminhwajegugbang. Treatment involves early wound healing, followed by later reparative and remodeling therapy in reduction ${ }^{13)}$.

The fracture-healing process is divided into the inflammatory, reparative, and remodeling phases. In the inflammatory phase, hematomas develop around the damaged bone, soft tissue, and blood vessels. Extravasated blood in Eastern medicine encompasses the meaning of these hematomas ${ }^{1)}$. In this study, we tried to investigate the effects of YJS on fracture recovery in rats using YJS to remove extravasated blood when the fracture occurred $^{14)}$.

YJS is effective in removing extravasated blood. YJS can be applied to bruises and fractures ${ }^{10)}$. YJS has been shown to reduce pain and bruises in traffic accident patients ${ }^{12)}$ and to be effective for $\operatorname{arthritis}^{11)}$.

Bone formation indicators measure enzymes or proteins produced by osteoblasts or components released during bone formation. Ingredients can be measured in serum osteocalcin, bone alkaline phosphatase (B-ALP), total alkaline phosphatase 


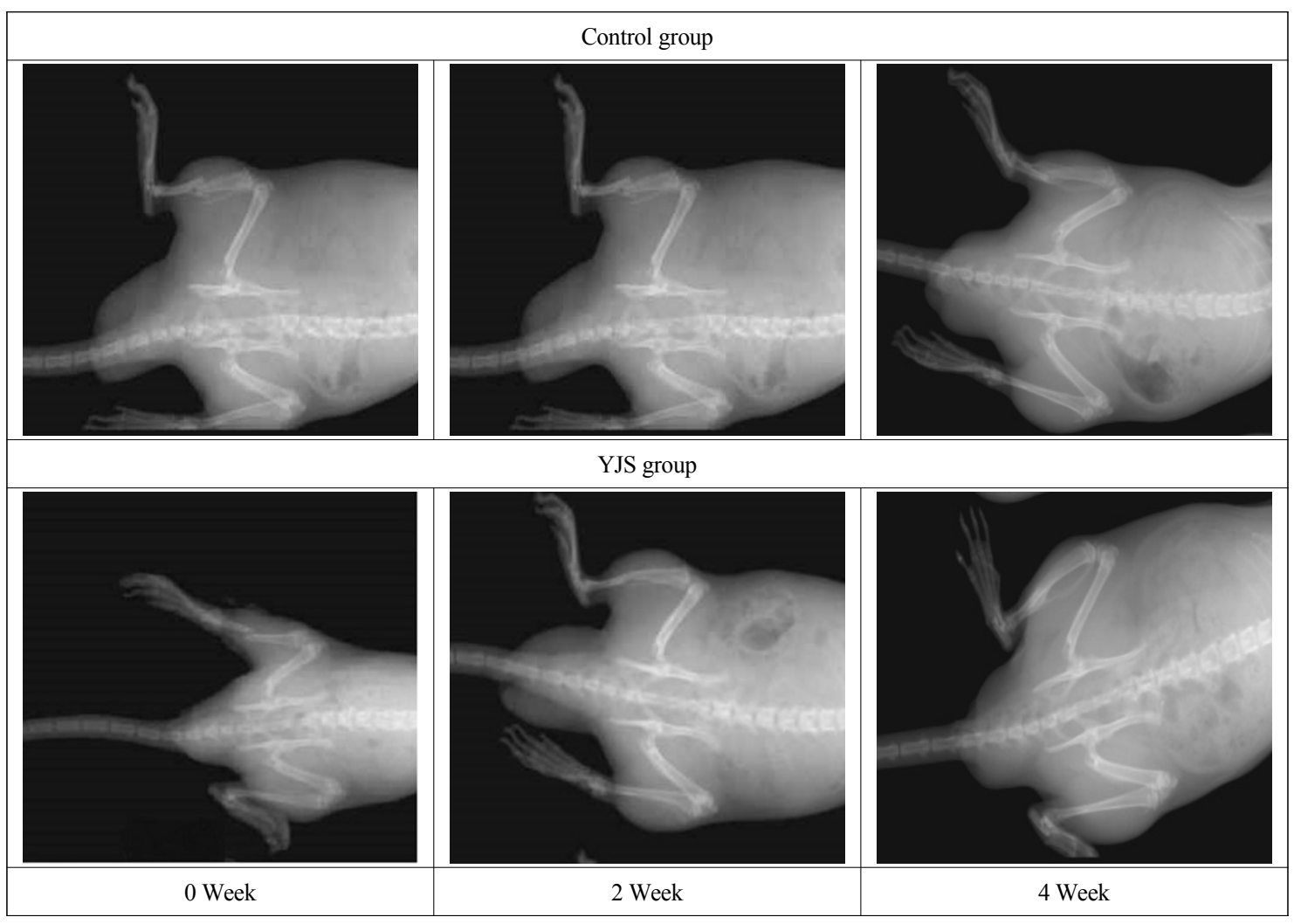

Fig. 7. X-ray Image of YJS and contral group on tibia fracture on 0,2 and 4 weeks.

(T-ALP), and procedure I extension peptides $(\mathrm{PICP})^{15)}$

The most useful of these is osteocalcin. By measuring its concentration, one can predict the degree of bone formation. This is an indicator reflecting the late differentiation of osteoblasts ${ }^{16)}$. As a result of measuring the serum osteocalcin change, osteocalcin was found to be significantly increased at 4 weeks.

Calcitonin is a parathyroid hormone, which is important for regulating calcium metabolism. Even if the blood calcium levels rise slightly, calcitonin acts on osteoclasts and inhibits their function. In other words, increased levels of calcitonin reflect the inhibition of bone resorption ${ }^{17)}$. At 4 weeks, the serum production of calcitonin was increased compared with that of the control group.

CTX-2 is a collagen substance that is released into the blood when there is bone damage ${ }^{18)}$. Serum CTX-2 production was significantly decreased at 3 weeks compared with that of the control group.

TGF- $\beta$ is a growth factor that plays an important role in bone formation. In fracture healing, TGF- $\beta$ is secreted by platelets. It is synthesized by osteoblasts and chondrocytes and increases bone and cartilage formation ${ }^{19}$. In this study, the expression level of TGF- $\beta$ during fracture healing was significantly increased at 3 
weeks.

BMP-2 is a genetic protein that converts fibroblasts into osteoblasts and plays a very important role in bone formation. In addition to BMP-2, BMP-4 and BMP-7 have a wide variety of effects on bone formation and growth. BMP-2 is known to induce strong allogeneic and heterologous bone formation in vivo ${ }^{20)}$. In this study, the BMP-2 concentration, which had increased up to 2 weeks, decreased significantly at 4 weeks.

X-rays were taken at 0,2 , and 4 weeks to determine the effects of YJS on fracture restoration. In the control group, fracture boundaries were clearly visible from weeks 0 to 4 . However, in the YJS group, fracture union progressed rapidly. In the comparison between the two groups, the YJS-administered group completed restoration faster.

As such, YJS promotes bone formation and suppresses bone resorption in the healing process of fractures and promotes fracture recovery through the regulation of hormones. Based on these findings, YJS could be effective for fracture healing.

\section{Conclusion}

The purpose of this study was to investigate the effects of YJS on fracture recovery. As a result, the following conclusions were derived.

1. YJS showed no cytotoxicity up to $200 \mu$ $\mathrm{g} / \mathrm{ml}$.

2. Osteocalcin showed a significant increase compared with the control at 4 weeks.

3. Calcitonin showed a significant increase compared with the control at 4 weeks.

4. CTX 2 showed a significant decrease compared with the control at 3 weeks.

5. TGF- $\beta$ showed a significant increase compared with the control at 3 weeks.

6. BMP-2 showed a significant decrease compared with the control at 4 weeks.

7. The group treated with YJS on X-ray promoted fracture recovery.

As described above, YJS administration showed significant results for factors related to fracture repair. X-rays were also found to facilitate fracture repair. Thus, YJS could be used to treat fractures in future clinical trials.

\section{Acknowledgements}

This work was supported by the National Research Foundation of Korea (NRF) grant funded by the Korea government (MSIP; Ministry of Science, ICT \& Future Planning) (No. NRF-2017R1C1B5017799)

\section{Acknowledgements}

This work was supported by the National Research Foundation of Korea (NRF) grant funded by the Korea government (MSIP; Ministry of Science, ICT \& Future Planning) (No. NRF-2017R1C1B5017799)

\section{References}

1. Korean Orthopedic Society. Orthopedic Surgery. 2nd. Seoul : The newest medicine. 2013 :216-32.

2. Choi PB Long-term Combined Exercise has Effect on Regional Bone Mineral Density and Cardiovascular Disease Risk Factors of the Elderly with Osteoporosis. J. of the Korean Gerontological. 2011;31(2):355-69. 
3. Park $\mathrm{CH}, \mathrm{Ha} \mathrm{CW}$, Park SJ, Ko MS, Son WJ. Fixation of the Femoral Subtrochanteric Fracture with Minimally Invasive Reduction Techniques. J Korean Fract Soc. 2013;26(2): 112-7-69.

4. Blythe JG and Buchshaum HJ. Fracturehealing in estrogen-treated and castrated rats. Obstetrica \&gynecology. 1976:351-2.

5. Gi YB, Kim DH, Kang DH, Kim SJ, Choi JB. Effects of Yukmijihwang-tang (Liuweidihuang -tang) and Cervi Pantotrichum Cornu Pharmacopuncture on Fracture Healing in Diabetic Rats. J. Oriental Reheb. Med. 2012; 22(3):49-63.

6. An HL, Shin MS, Kim SJ, Choi JB. Effects of Neutral Eohyeol(Yuxue) Herbal Acupuncture and Dangkisoo-san(Dangguixu-san) on Fracture Healing in the Early Stage in Rats. J Oriental Rehab Med 2007;17(1):1-16.

7. Shin KM, Jeong CY, Hwang MS, Lee SD, Kim KH, Kim GS. Effects of Administration of Pyritum on Fracture Healing in Mice. The journal of Korean Acupuncture \& Moxibustion Society. 2009;26(5):65-75.

8. Lee HG, Oh MS. Effects of Jeopgolsan (JGS) Extract on Fracture Healing. J. Oriental Reheb. Med. 2018;28(1):1-17.

9. Keum DH, Kim SS. Healing Effect of Bokwonhwalhyul-tang on Tibia fractured Rats. The Journal of The Korean institute medical informatics. 2002;8(1):46-66.

10. Heo Joon. Donguibogam. 3rd. Seoul: Donguibogam publisher. 2006:1663-5.

11. Park JW, Jeong SH. Effect of Dangguisoo-san plus Yuhyangjeongtong-san (Dangguixu-san plus Ruxiangdingtong-san) in the Traffic Accidents Patients with Night Pain. J. Oriental Rehab Med. 2015;25(1):87-93.
12. An HB, Jeong SH, Kim SJ, Park DS, Seo IB. Effects of Yuhyangjeongtong-san on the Carrageenin-induced Acute Inflammation and Adjuvant-induced Arthritis. J. Oriental Rehab Med. 2013;23(3):55-63.

13. Kim KU, Chinese Medicine. 1st. Seoul : Daesung medicine. 2006 :306-18.

14. Jhon BH, Woo WH, Jeong WY. Study on the Oriental Medical Concept of Blood Stasis. Journal of physiology \& pathology in Korean Medicine. 1989;4(1):93-102.

15. $\mathrm{M} \mathrm{T}$ Nyman, $\mathrm{P}$ Paavolainen, $\mathrm{S}$ Forsius, $\mathrm{C}$ Lamberg-Allardt.Clinical evaluation of fracture healing by serum osteocalcin and alkaline phosphatase. Annales chirurgiae et gynaecologiae. 1991;80(3):289-382.

16. Fiona McGuigan, Jitender Kumar, Kaisa K Ivaska, Karl J Obrant, Paul Gerdhem, Kristina Åkesson. Osteocalcin gene polymorphisms influence concentration of serum osteocalcin and enhance fracture identification. Journal of bone and mineral research. 2010;25(6):1392-9.

17. J Schatzker, M Chapman, G B Ha'Eri, V L Fornasier, G Sumner-Smith, C Williams. The effect of calcitonin on fracture healing. Clinical Orthopaedics and Related Research. 1979;141(1):303-9.

18. A Moghaddam, U Müller, H J Roth, A Wentzensen, P A Grützner, G Zimmermann. TRACP $5 b$ and CTX as osteological markers of delayed fracture healing. Injury: international journal of the care of the injured. 2011;42(8): 758-822.

19. G Zimmermann, A Moghaddam, M Reumann, B Wangler, L Breier, A Wentzensen, et al. TGF-betal as a pathophysiological factor in fracture healing. Unfallchirurg, Der. 2007;100(2): 130-6. 
20. Rosen Vicki. BMP2 signaling in bone development and repair. Cytokine and Growth Factor Reviews. 2009;20(5):475-80.

\section{ORCID}

Ki-tae Kim https://orcid.org/0000-0003-4892-3472

Na-young JO https://orcid.org/0000-0003-2802-2626 